\title{
PENGEMBANGAN BUKU PETUNJUK PRAKTIKUM UJI FORMALIN DAN BORAKS UNTUK SISWA SMP
}

\author{
Nanang Rahman*, Nursina Sari \\ ${ }^{1}$ Program Studi Pendidikan Guru Sekolah Dasar, Universitas Muhammadiyah Mataram, nangrhm87@gmail.com
}

\section{INFO ARTIKEL}

Riwayat Artikel:

Diterima :28-12-2018

Disetujui :09-01-2019

\section{Kata Kunci:}

Pengembangan

Petunjuk Praktikum

Uji Formalin dan Borak

\begin{abstract}
ABSTRAK
Abstrak: Tujuan penelitian ini adalah untuk mengembangkan buku petunjuk praktikum uji formalin dan boraks dengan menggunakan indicator alami untuk siswa sekolah menegah pertama. Metode penelitian ini mengacu pada prosedur pengembangan dikembangkan oleh Borg \& Galls. Uji coba terhadap 94 sampel daun dan mahkota bunga yang diperkirakan memiliki potensi sebagai indikator alami untuk uji formalin dan boraks telah dilakukan. indikator alami yang dapat digunakan untuk uji tetes boraks, yaitu: bunga Ruellia Simplex, Curcuma Longa, Plumeria Rubra,dan Portulaca Grandiflora. Sedangkan untuk uji formalin dapat menggunakan Ruellia Ribosa, Hibiscus Rosa-Sinensis L dan Balsamina Impatiens L. Berdasarkan hasil penilaian ahli dan guru menunjukkan bahwa buku petunjuk praktikum telah layak digunakan untuk siswa Sekolah Menengah Pertama untuk menguji formalin dan boraks.
\end{abstract}

\section{A. LATAR BELAKANG}

Saat ini Indonesia masih menggunakan formalin dan boraks untuk makanan, bahan ini sering digunakan sebagai camilan tambahan [1]. Formalin adalah zat karsinogenik dan telah diketahui menyebabkan efek negatif pada kesehatan manusia. Paparan akut menyebabkan iritasi di mata, hidung dan tenggorokan. Paparan yang sering juga dapat menyebabkan reaksi alergi yang parah pada kulit, mata, dan saluran pernapasan. Paparan kronis untuk formaldehida menghasilkan gejala neurasthenia, yang termasuk sakit kepala, pusing, gangguan tidur, dan kehilangan memori [2]. Sementara dosis boraks 200-640 mg asam borat / $\mathrm{kg}$ telah dilaporkan mematikan, tetapi jumlahnya belum sepenuhnya diverifikasi [3]. Laporan lain menyatakan bahwa dosis mematikan terendah setelah menelan secara tidak sengaja asam borat oleh manusia berkisar dari sekitar 98 hingga $650 \mathrm{mg}$ boron / kg berat badan [4] Kematian telah dilaporkan ketika boron diberikan secara intravena pada $0,5 \mathrm{mg}$ boron / $\mathrm{kg}$ berat badan [5].

Ada berbagai penelitian dalam identifikasi formalin yang telah dilakukan, pengembangan metode fluorophotometric untuk penentuan formaldehida di perairan lingkungan, berdasarkan reaksi formaldehida dengan acetoace-tanilide dan amonia [6]. Penentuan tingkat formaldehida dalam air liur manusia. Formaldehida ditentukan sebagai tambahan untuk dimedone (formaldemethone) menggunakan OPLC [7].
Penentuan total formaldehida dalam sampel air minum dalam 1 liter air diderivatisasi dengan 2,4dinitrofenilhidrazin dalam media asam dan kemudian diekstraksi dengan kloroform. Setelah pemisahan dengan ekstraksi pelarut, produk dikonfirmasi menggunakan kromatografi fase cair terbalik [8]. Pada tahun 2010 diusulkan metode kinetik katalitik yang sederhana dan cepat (berdasarkan efek katalitik formaldehida pada oksidasi cresilviolet oleh bromat dengan adanya asam sulfat) untuk penentuan jumlah formaldehida dalam sampel air. Metode identifikasi formalin yang paling banyak digunakan untuk sampel berair adalah kromatografi cair kinerja tinggi (HPLC). Metode lain yang dapat digunakan adalah kolorimetri, fluorimetri, polarografi, kromatografi gas (GC), deteksi inframerah, analisis aliran injeksi dan tabung detektor gas [9]. HPLC atau GC dikombinasikan dengan spektrometer massa (MS) adalah teknik yang paling sensitif, tetapi membutuhkan biaya yang sangat mahal.

Ada beberapa metode yang telah digunakan untuk menguji keberadaan boraks. Ada tiga metode yang dikenal untuk menentukan asam borat rinci dalam makanan, yaitu metode titrimetri menggunakan manitol, dan dua prosedur kolorimetri menggunakan asam carminic atau kurkumin. Prosedur kolorimetrik dengan metode kurkumin ditemukan menjadi yang paling dapat diandalkan dan oleh karena itu akan menjadi metode pilihan untuk penentuan asam borat dalam makanan [10]. Metode lain adalah analisis kuantitatif cepat asam 
borat dengan spektrometri kromatografi gas ditambah dengan reaksi derivatif sederhana dan selektif menggunakan trietanolamina [11].

Metode untuk menguji formalin dan boraks yang dijelaskan di atas mahal dan kurang layak untuk pengajaran di ruang kelas, khususnya untuk diterapkan bagi siswa di sekolah. Metode alternatif harus dikembangkan menggunakan prosedur sederhana, biaya rendah, dan dapat diakses [12]. Uji kualitatif formalin dan borak dapat menggunakan indikator alami dari tanaman di sekitar lingkungan sehingga harganya murah dan mudah diperoleh. Siswa di sekolah dapat menggunakan tes kualitatif ini untuk mengidentifikasi keberadaan formalin dan boraks.

Berdasarkan hasil observasi disekolah dan wawancara dengan guru IPA yang ada di provinsi Nusa Tenggara Barat, menyatakan bahwa tidak pernah melakukan praktikum uji formalin dan borak yang merupakan materi wajib pada pokok bahasan zat aditif pada makanan. Sehingga diperlukan pengembangan buku petenjuk praktikum uji formalin dan borak yang dapat digunakan oleh Siswa Sekolah Menengah Pertama.

\section{B. METODE PENELITIAN}

\section{Metode Penelitian}

Prosedur pengembangan yang digunakan dalam penelitian dan pengembangan ini adalah pengembangan secara prosedural dimana langkah-langkahnya dijelaskan secara kongkrit dan rinci. Prosedur pengembangan yang dilakukan mengacu kepada prosedur yang dikembangkan oleh Borg \& Galls [13]. Borg dan Gall mengemukan bahwa prosedur penelitian pengembangan pada dasarnya terdiri dari dua tujuan utama, yaitu mengembangkan produk dan memvalidasi produk yang dihasilkan. Adapun penjabaran dari model pengembangan ini dijelaskan pada Gambar 1 berikut.

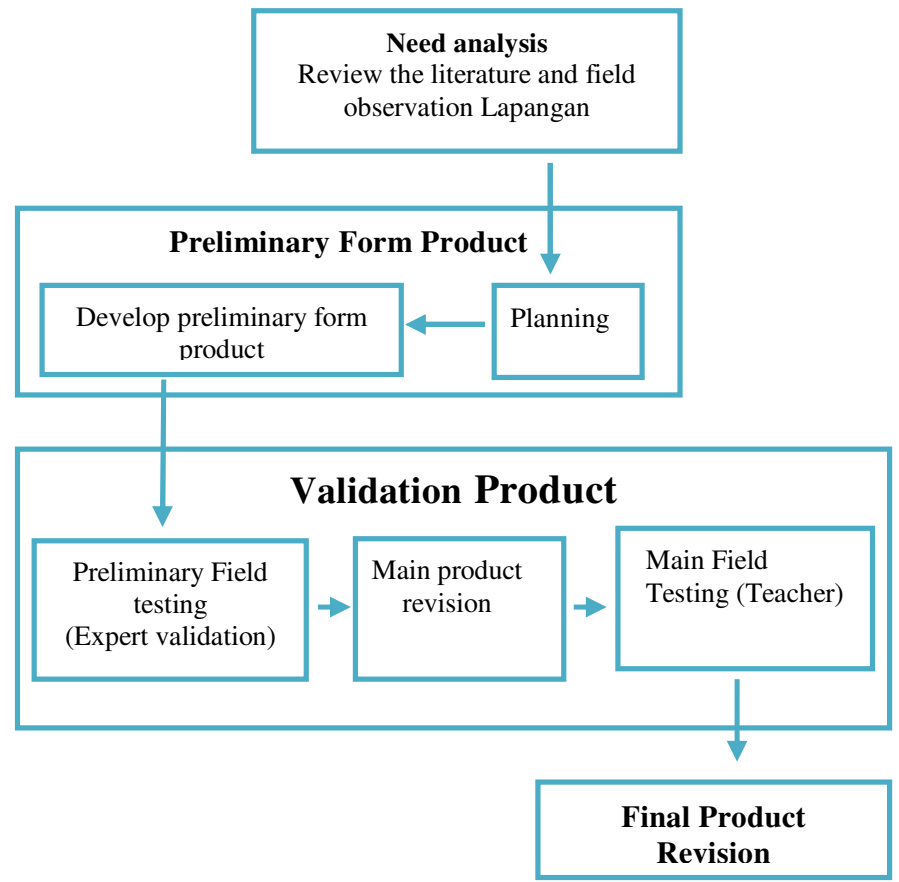

Gambar 1. Model pengembangan
Rincian dari prosedur penelitian yang telah dilakukan sebagai berikut:

1. Melakukan kegiatan studi pustaka yaitu kajian literatur yang relevan dengan penelitian. Studi pustaka dilakukan untuk mengumpulkan infomasi, diantaranya dengan mempelajari kurikulum mata pelajaran IPA terpadu untuk Sekolah Menengah Pertama, mengkaji literatur tentang sifat fisika dan kimia formalin serta boraks. Observasi lapangan dilakukan untuk melihat secara langsung keadaan lingkungan sekolah, potensipotensi sumber daya alam yang dapat dimanfaatkan sebagai indikator alami. Observasi lapangan dilakukan di Provinsi Nusa Tenggara Barat.

2. Planning percobaan praktikum uji formalin dan boraks dengan indikator alami. Rancangan Petunjuk Praktikum diawali dengan percobaan laboratorium menggunakan bahan murni senyawa boraks dengan menggunakan berbagai jenis bahan alami yang ada disekitar lingkungan. Pada tahap ini juga mulai dirancang bahan sederhana untuk indikator uji formalin dan boraks. Metode praktikum uji formalin dan boraks dengan indikator alami menggunakan uji tetes sebagai berikut:

-Menimbang 2 gram bahan indikator alami, kemudian di potong kecil-kecil

-Menggerus indikator alami dengan dengan menggunakan mortal

-Tambahkan $5 \mathrm{ml}$ aquades ke dalam indikator yang telah digerus

- Pisahkan filtrat dengan residu indikator

-Ambil 5 tetes filtrat indikator kemudian tambahkan dengan 5 tetes larutan formalin dan boraks

-Amati perubahan warna yang terjadi

Uji tetes indikator alami dari ekstrak tanaman bunga dilakukan percobaan selama 3 kali untuk setiap indikator. Ekstrak tanaman bunga yang dapat digunakan sebagai indikator adalah yang dapat menunjukkan perubahan warna sebelum dan setelah ditambahkan borax.

3. Develop preliminary form product dengan menggunakan kertas saring untuk alat sederhana uji formalin dan boraks. Indikator alami yang telah berhasil dengan uji coba tetes, kemudian dikembangkan menjadi uji dengan kertas saring. Cara pembuatan kertas indikator sebagai berikut:

- Potong kertas saring dengan ukuran panjang 7 cm dan lebar $0.5 \mathrm{~cm}$

- Celupkan kertas saring kedalam filtrat indikator

- Keringkan selama 4 jam sampai kertas indikator dapat digunakan

Langkah praktikum uji formalin dan boraks dengan indikator alami tersebut kemudian disusun dalam 
petunjuk praktikum yang dapat digunakan oleh siswa sekolah menengah pertama.

4. Preliminary Field testing dengan melakukan validasi oleh 1 orang ahli kimia dan 1 orang ahli pendidikan sains. Untuk melakukan validasi digunakan angket yang berisikan 3 aspek penilaian: keterbacan, kegrafikan dan kepraktisan penggunaan

5. Main product revision berdasarkan masukan dari validasi ahli. Revisi dapat dilakukan berdasarkan penilaian tampilan petunjuk praktikum (keterbacaan dan kegrafikan) atau temuan indikator ekstrak bunga yang dapat digunakan dengan uji tetes dan uji kertas saring (kepraktisan penggunaan)

6. Main Field Testing dilakukan kepada 8 orang guru di beberapa sekolah yang ada di Provinsi Nusa Tenggara Barat. Uji coba kepada guru untuk mendapatkan pendapat tentang petunjuk praktikum yang dikembangkan dari aspek: keterbacaan, kegrafikan dan kepraktisan pengunaan.

7. Final revision dilakukan berdasarkan masukan dari guru setelah melakukan penilaian terhadap petunjuk praktikum yang telah dikembangkan.

\section{Instrumen Penelitian}

Instrumen yang digunakan dalam dalam penelitian ini adalah angket kelayakan produk yang telah dikembangkan. Preliminary Field testing diberikan angket kepada ahli kimia dan ahli pendidikan sains. Main field testing diberikan angket kepada 8 orang guru yang ada di beberapa sekolah yang ada diprovinsi Nusa Tenggara Barat. Angket yang digunakan berisikan 3 aspek penilaian: keterbacan, kegrafikan dan kepraktisan penggunaan. Aspek keterbacaan: petunjuk penggunaan buku praktikum uji formalin dan boraks dengan indikator alami mudah dipahami, pernyataan dan kalimat pada petunjuk praktikum uji formalin dan boraks dengan indikator alami mudah dipahami, ukuran dan model huruf yang digunakan pada petunjuk praktikum uji formalin dan boraks terlihat dengan jelas dan mudah digunakan. Aspek kegrafikan: gambar pada petunjuk praktikum uji formalin dan boraks dengan indikator alami terlihat menarik dan jelas, Cover pada petunjuk praktikum uji formalin dan boraks dengan indikator alami terlihat menarik. Aspek kepraktisan penggunaan: pemakaian petunjuk praktikum uji formalin dan boraks dengan indikator alami mudah digunakan, penggunaan waktu lebih efektif saat praktikum dengan petunjuk praktikum uji formalin dan boraks dengan indikator alami, informasi yang diberikan pada petunjuk praktikum boraks dengan indikator alami membuat praktikum lebih aktif, kreatif, dan menyenangkan, Bentuk alat uji boraks terlihat menarik, prosedur dan langkah- langkah kerja disajikan terstruktur dengan jelas dan mudah digunakan, alat uji formalin dan boraks mudah digunakan dalam proses pelaksanaan praktikum

\section{Analisi Data}

Lembar angket kelayakan produk perangkat Uji formalin dan boraks diberikan kepada ahli dan guru. Data yang diperoleh dari lembar kuesioner diubah menjadi data interval. Kuesioner yang diberikan berisikan lima pilihan untuk memberikan tanggapan tentang produk buku petunjuk praktikum yang telah dikembangkan, yaitu: sangat baik (5), baik (4), cukup baik (3), kurang baik (2) dan sangat kurang baik (1). Bila responden memberikan tanggapan "sangat baik" maka pada butir pernyataan diberi angka "5" dan begitu juga berlaku untuk yang lainnya. Skor yang diperoleh kemudian dikonversikan menjadi nilai pada skala 5 dengan acuan Tabel yang dikutip dari Saifuddin Azwar [14], seperti berikut ini:

Tabel 1

Konversi Skor Aktual menjadi Nilai Skala Lima

\begin{tabular}{|c|c|c|}
\hline Interval Skor & Nilai & Kategori \\
\hline $\mathbf{X}>\mathrm{x}_{\mathrm{i}}+1,5 \mathrm{SB}_{\mathrm{i}}$ & $\mathrm{A}$ & Sangat baik \\
$\mathrm{x}_{\mathrm{i}}+0,5 \mathrm{SB}_{\mathrm{i}}<\mathbf{X} \leq \mathrm{x}_{\mathrm{i}}+1,5 \mathrm{SB}_{\mathrm{i}}$ & $\mathrm{B}$ & Baik \\
$\mathrm{x}_{\mathrm{i}}-0,5 \mathrm{SB}_{\mathrm{i}}<\mathbf{X} \leq \mathrm{x}_{\mathrm{i}}+0,5 \mathrm{SB}_{\mathrm{i}}$ & $\mathrm{C}$ & Cukup baik \\
$\mathrm{x}_{\mathrm{i}}-1,5 \mathrm{SB}_{\mathrm{i}}<\mathbf{X} \leq \mathrm{x}_{\mathrm{i}}-0,5 \mathrm{SB}_{\mathrm{i}}$ & $\mathrm{D}$ & Kurang baik \\
$\mathbf{X} \leq \mathrm{x}_{\mathrm{i}}-1,5 \mathrm{SB}_{\mathrm{i}}$ & $\mathrm{E}$ & Sangat kurang baik \\
\hline
\end{tabular}

\section{Keterangan:}

$\mathrm{x}_{\mathrm{i}}=$ Rerata skor ideal $=\frac{1}{2}$ (skor maksimal ideal + skor minimal ideal)

SBi $=$ Simpangan baku ideal $=1 / 6$ ( skor maksimal ideal - skor minimal ideal)

$\mathbf{X}=$ Skor aktual (skor yang dicapai)

Skor maksimal ideal $=\sum$ butir kriteria $\mathrm{x}$ skor tertinggi Skor terendah ideal $=\sum$ butir kriteria $\mathrm{x}$ skor terendah

\section{HASIL DAN PEMBAHASAN}

Identifikasi awal tanaman yang digunakan sebagai indikator alami untuk menguji formalin dan boraks adalah yang memiliki warna yang cerah selain putih, karena warna larutan boraks berwarna putih bening. Ada dua bagian tumbuhan yang digunakan sebgai bahan uji, yaitu daun dan mahkota bunga. Berdasarkan hasil observasi lapangan yang telah dilakukan terhadap tanaman yang ada di wilayah Provinsi Nusa Tenggara Barat, maka diambil 94 sampel daun dan mahkota bunga yang diperkirakan memiliki potensi sebagai indikator alami untuk uji formalin dan boraks.

Berdasarkan hasil uji coba larutan formalin 10\% menggunakan berbagai bahan yang telah diidentifikasi, 3 sampel indikator dapat digunakan, yaitu: ruellla ribosa, hibiscus rosa-sinensis $L$ dan impatiens balsamina $L$ ungu. Berikut ini adalah 
hasil dari percobaan formalin 10\% dengan 3 jenis indikator.

Tabel 2

Hasil uji indikator formalin

\begin{tabular}{|l|ll|}
\hline Natural indicator & Hasil uji tetes & \\
\hline Ruellla Ribosa & BEFORE & \\
\hline $\begin{array}{l}\text { Hibiscus Rosa- } \\
\text { Sinensis L. }\end{array}$ & BEFORE & \\
\hline $\begin{array}{l}\text { Impatiens } \\
\text { Balsamina L. }\end{array}$ & BEFORE \\
\hline
\end{tabular}

Secara umum, warna bunga disebabkan oleh pigmen flavonoid dan karotenoid yang dapat menarik perhatian untuk membantu penyerbukan [13]. Flavonoid adalah pigmen warna bunga yang paling umum, dan pigmen flavonoid dominan adalah anthocyanin. Anthocyanin terdiri dari kelompok anthocyanidin dan gula. Mereka adalah dasar untuk sebagian besar warna oranye, merah muda, merah, magenta, ungu, biru, dan biru-hitam. Antosianidin yang umum adalah pelargonidin, sianidin, peonidin, delphinidin, petunidin, dan malvinidin, dinamai sesuai genera yang pertama kali mereka isolasi. Kebanyakan anthocyanin hanya berasal dari tiga anthocyanidin dasar berikut: pelargonidin, sianidin, dan delphinidin [14].

Indikator alami pertama yang dapat digunakan sebagai zat untuk mengidentifikasi formalin adalah ribose ruellia. Zat warna yang terkandung dalam ribosa dengan warna ungu ruellia adalah anthocyanin [15]. Anthocyanin adalah komponen biokatif dari kelompok flavanoid yang ditemukan pada bunga, daun, ubi jalar, buah-buahan dan sayuran yang menempel pada Ph dari lingkungan di mana mereka berada [16] [17]. Perubahan $\mathrm{Ph}$ menyebabkan perubahan struktur quinonoidal anhydrobase (A) $\mathrm{Ph} 6,5-8$ menjadi Karbinol (B) $\mathrm{Ph}<6$ [18]. Larutan formalin yang memiliki Ph sekitar 2,8-4,0 bila dicampur dengan ekstrak ribosa ruellia dengan warna ungu akan mengalami perubahan warna biruhijau karena perubahan struktural. Perubahan struktur yang menyebabkan perubahan warna komplemen yang dapat diamati sebagai indikator untuk menentukan keberadaan formalin dalam sampel.

Indikator alami kedua yang dapat digunakan adalah hibiscus rosa-sinensis l. Hibiscus anthocyanin adalah pigmen alami fenolik yang diekstraksi dari bunga kering Hibiscus yang telah digunakan secara efektif dalam obat-obatan rakyat melawan hipertensi, pireksia dan gangguan hati. Pigmen yang terkandung dalam owers spesies Hibiscus adalah anthocyanin seperti cyanidin-3-glukosida dan delphinidin-3-glukosida [19] [20]. Ph memiliki efek besar pada warna anthocyanin.
Mereka berwarna lebih merah dan lebih intens pada warna rendah (asam) $\mathrm{Ph}$ dan lebih biru dan kurang intens dalam warna pada $\mathrm{Ph}$ yang lebih tinggi. Perubahan struktur anhidroase yang memiliki Ph 6-7 berwarna kebiruan ke struktur tanpa warna. carbinol pseudabase $\mathrm{Ph}<4$ dan kation flavylium yang memiliki $\mathrm{Ph}>3$ warna kemerahan [21]. Berdasarkan hasil penelitian yang telah dilakukan diketahui bahwa bunga hibiscus rosa-sinensis $\mathrm{L}$ dapat digunakan sebagai indikator uji formalin karena dapat mengalami perubahan warna dari kebiruan menjadi merah jambu.

Indikator ketiga yang dapat digunakan untuk mengidentifikasi keberadaan formalin adalah bunga impatiens balsamina l. Tunggu. Warna impatiens balsamina 1 bunga disebabkan oleh anthocyanin [22]. Perubahan struktur anthocyanin terjadi dari struktur quinonoidal anhydrobase (A) $\mathrm{Ph} 6.5$ hingga 8 hingga Karbinol (B) $\mathrm{Ph}<6$ [18]. Perubahan ini hampir sama dengan perubahan yang terjadi pada bunga ruellia ribose. Dengan perubahan ini, impatiens balsamina L bunga dapat digunakan sebagai indikator formalin.

Berdasarkan hasil uji coba larutan Borak 0,1 M menggunakan berbagai ekstrak tanaman yang telah diidentifikasi, 4 sampel ekstrak memberikan reaksi positif, yaitu: Ruella Simplex, Curcuma Longa, Plumeria Rubca, dan Portulaca Grandiflora. Berikut ini adalah hasil dari percobaan boraks o, $1 \mathrm{M}$ dengan 4 jenis indikator

Table 3

Hasil uji indikator borak

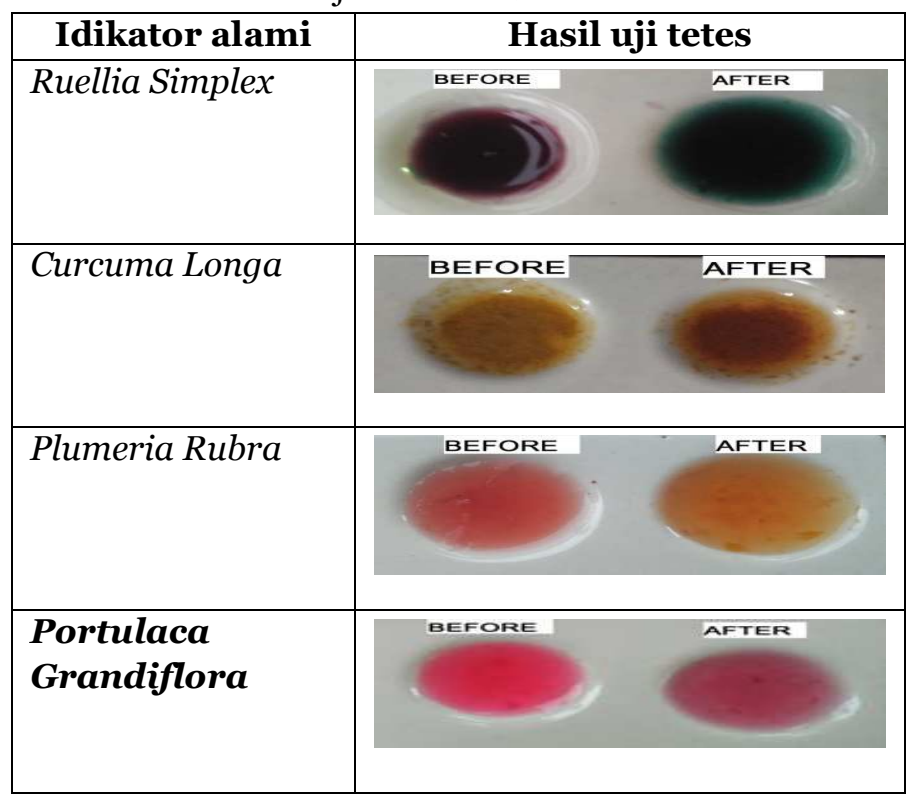

Indikator alami pertama yang digunakan sebagai ekstrak untuk mengidentifikasi boraks adalah simpleks rellia. Zat warna yang terkandung dalam ruellia simplex dengan warna ungu adalah anthocyanin [15]. Anthocyanin adalah komponen bioaktif dari kelompok flavonoid yang ditemukan dalam bunga, daun, ubi jalar, buah-buahan dan sayuran yang menempel pada Ph dari lingkungan di mana mereka berada [16] [17]. Struktur anthocyanin berubah pada $\mathrm{Ph} \mathrm{1,} \mathrm{Ph} \mathrm{4,5} \mathrm{dan} \mathrm{Ph} 7$ [23]. 
Perubahan $\mathrm{Ph}$ menyebabkan perubahan struktur quinonoidalanidrobase $\mathrm{Ph} 6.5^{-8}$ ke cis-chalcone $\mathrm{Ph}>9$ [18]. Larutan Borax yang memiliki Ph sekitar 9,5 ketika ditambahkan tetes bijaksana untuk ekstrak Ruellia simplex yang menunjukkan warna ungu akan mengalami perubahan warna biru-hijau karena perubahan struktural. Perubahan struktural menyebabkan perubahan warna komplemen yang dapat diamati sebagai indikator untuk menentukan keberadaan boraks dalam sampel.

Indikator alami kedua yang digunakan untuk mengidentifikasi boraks adalah kunyit. Kunyit mengandung bahan utama warna kuning yang dikenal sebagai kurkumin [24]. Curcumin (1,7-Bis- (4-hydroxy3methoxyphenyl) -hepta-1,6-diene-3,5-dione) adalah pigmen yang larut dalam minyak, praktis tidak larut dalam air pada $\mathrm{pH}$ asam dan netral, larut dalam alkali dan bentuk yang sangat rentan dari perubahan $\mathrm{Ph}$ [25]. Namun, dalam sistem berair seperti air, dapat dipahami bahwa pada alkalin $\mathrm{Ph}$, asam golongan fenol dalam kurkumin menyumbangkan hidrogen, membentuk ion fenolik yang memungkinkan kurkumin larut dalam air. Bentuk ini tidak stabil pada pH netral dan alkalin untuk jangka waktu yang lebih lama dan mudah terdegradasi menjadi senyawa seperti vanilin, asam ferulat, dll. Bentuk ini stabil pada $\mathrm{Ph}$ di bawah 7,0 tetapi dengan penurunan nilai $\mathrm{Ph}$, pergeseran disosiasi ekuilibrium ke bentuk netral dengan kelarutan air yang sangat rendah [26]. Kurkumin yang diperoleh dari kunyit dapat digunakan untuk menguraikan ikatan boraks menjadi asam borat dan mengikatnya menjadi kompleks warna rosa atau biasa disebut kompleks senyawa boron sianokurkumin yang merupakan zat berwarna merah. Perubahan warna dari kuning menjadi kemerahan pada kunyit dapat digunakan sebagai bahan indikator alami untuk mendeteksi keberadaan boraks dalam kegiatan laboratorium.

Bunga ketiga yang dapat digunakan sebagai bahan indikator alami adalah bunga Plumeriarubra. Dua anthocyanin diisolasi dari bunga hias kemerahan Plumeria rubra L. (Apocynaceae) dengan kombinasi teknik kromatografi. The anthocyanin cyanidin 3-O- (2glucopyranosyl-O-galactopyranoside)

$(75 \%)$ sebelumnya telah diisolasi hanya dari buah Cornus suecica (Cornaceae), sementara yang lain (20\%) diidentifikasi sebagai cyanidin-3-O- galactopyranoside [27]. Anthocyanin menyebabkan warna merah ke biru pada tumbuhan [24]. Perubahan warna yang terjadi pada ekstrak plumeriarubra setelah dicampur dengan larutan boraks yang disebabkan oleh perubahan struktur anthocyanin pada $\mathrm{Ph}$ 9,5 seperti pada bunga simplex ruellia.

Indikator keempat yang dapat digunakan untuk mengidentifikasi boraks adalah bunga Portulaca Grandiflora yang merupakan ordo tanaman Caryophyllies. Betalain adalah pigmen yang menggantikan anthocyanin di sebagian besar famili tanaman ordo Caryophyllales [28]. Dalam pengolahan makanan, betalain lebih jarang digunakan daripada anthocyanin dan karotenoid, meskipun pigmen yang larut dalam air ini, stabil antara $\mathrm{Ph} 3$ dan 7, cocok untuk mewarnai makanan rendah asam [29] [30] [31]. Jika Portulaca Grandiflora dicampur dengan larutan boraks yang memiliki $\mathrm{Ph}$ 9,5, itu akan mengubah struktur betalain sehingga warna akan berubah dari merah muda menjadi merah ungu. Perubahan warna ini membenarkan penggunaan Portulaca Grandiflora menjadi indikator alami untuk mengidentifikasi keberadaan boraks.

Setelah menemukan indikator alami yang dapat digunakan untuk pengujian formalin dan borak, kemudian buku petunjuk praktikum uji formalin dan boraks dikembangkan. Berikut cover petunjuk praktikum yang telah dikembangkan.

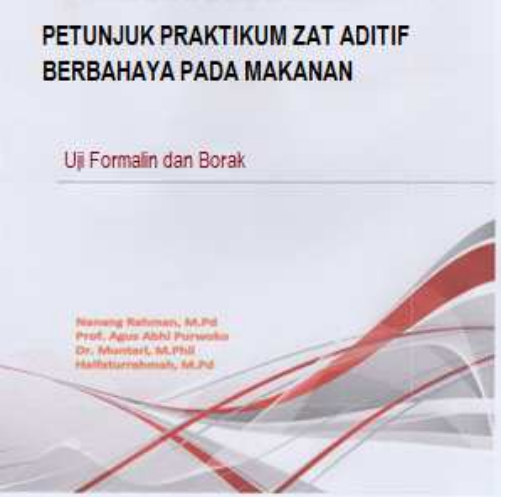

Gambar 2. Cover petunjuk praktikum

Buku petunjuk praktikum yang telah dikembangkan kemudian dilkaukan validasi oleh ahli dan dimintai tanggapan dari guru tentang kualitas produk buku yang telah dikembangkan. Berikut hasil valiadasi ahli dan penilaian oleh guru.

Tabel 4

Rerata hasil validasi ahli dan penilaian guru

\begin{tabular}{|l|c|c|c|}
\hline \multirow{2}{*}{$\begin{array}{c}\text { Aspek yang } \\
\text { dinilai }\end{array}$} & \multicolumn{3}{|c|}{ Nilai rata-rata } \\
\cline { 2 - 4 } & Ahli & Guru & Rata-rata \\
\hline Keterbacaan & 12,00 & 12,80 & 12,40 \\
\hline Grafik & 7,50 & 7,50 & 7,50 \\
\hline $\begin{array}{l}\text { Kepraktisan } \\
\text { penggunaan }\end{array}$ & 23,50 & 23,60 & 23,55 \\
\hline
\end{tabular}

Berdasarkan hasil kuesioner yang telah diberikan kepada para ahli dan guru ada beberapa masukan terkait dengan buku petunjuk praktikum yang telah dikembangkan:

1. Gambar bunga untuk indikator dibuat lebih jelas warnanya

2. Ukuran gambar lebih besar untuk membuatnya jelas

Berdasarkan hasil konversi skor pada tabel 1 kemudian hasil validasi dan penilaian guru dikonversi menjadi skala lima 
Tabel 5

Hasil konversi skala lima

\begin{tabular}{|c|c|c|c|}
\hline Aspect & Interval & Nilai & Kategori \\
\hline \multirow{5}{*}{$\begin{array}{l}\text { Keterbacaa } \\
\text { n }\end{array}$} & $\mathrm{X}>12,0$ & $\mathrm{~A}$ & Sangat baik \\
\hline & $\begin{array}{c}10,0<\mathrm{X} \leq \\
12,0\end{array}$ & B & Baik \\
\hline & $8,0<X \leq 10,0$ & $\mathrm{C}$ & Cukup baik \\
\hline & $6,0<X \leq 8,0$ & $\mathrm{D}$ & Kurang baik \\
\hline & $\mathrm{X} \leq 6,0$ & $\mathrm{E}$ & $\begin{array}{c}\text { Sangat } \\
\text { kurang baik }\end{array}$ \\
\hline \multirow[t]{5}{*}{ Grafik } & $\mathrm{X}>8,0$ & $\mathrm{~A}$ & Sangat baik \\
\hline & $6,6<X \leq 8,0$ & $\mathrm{~B}$ & Baik \\
\hline & $5,4<X \leq 6,6$ & $\mathrm{C}$ & Cukup baik \\
\hline & $4,0<X \leq 5,4$ & $\mathrm{D}$ & Kurang baik \\
\hline & $\mathrm{X} \leq 4, \mathrm{O}$ & $\mathrm{E}$ & $\begin{array}{c}\text { Sangat } \\
\text { kurang baik }\end{array}$ \\
\hline \multirow{5}{*}{$\begin{array}{l}\text { Kepraktis } \\
\text { an } \\
\text { pengunaa } \\
\text { n }\end{array}$} & $X>20,0$ & $\mathrm{~A}$ & Sangat baik \\
\hline & $\begin{array}{c}16,6<\mathrm{X} \leq \\
20,0 \\
\end{array}$ & B & Baik \\
\hline & $13,3<X \leq 16,6$ & $\mathrm{C}$ & Cukup baik \\
\hline & $\begin{array}{c}10,0<\mathrm{X} \leq \\
13,3\end{array}$ & $\mathrm{D}$ & Kurang baik \\
\hline & $X \leq 10,0$ & $\mathrm{E}$ & $\begin{array}{c}\text { Sangat } \\
\text { kurang baik }\end{array}$ \\
\hline
\end{tabular}

Hasil validasi ahli dan penilaian guru pada tabel 4 dibandingkan dengan tabel 5 untuk mengetahui kualitas petunjuk praktikum yang telah dikembangkan. Kesimpulan dari hasil penilaian sebagai berikut.

Table 6

Kesimpulan hasil penilaian petunjuk praktikum

\begin{tabular}{|l|c|c|c|}
\hline \multirow{2}{*}{$\begin{array}{c}\text { Aspek } \\
\text { penilaian }\end{array}$} & \multicolumn{3}{|c|}{ Rerata penilaian } \\
\cline { 2 - 4 } & $\begin{array}{l}\text { Nilai } \\
\text { rata-rata }\end{array}$ & Interval & Kategori \\
\hline Keterbacaan & 12.40 & $\mathrm{X}>12,0$ & Sangat baik \\
\hline Grafik & 7.50 & $\begin{array}{c}6,6<\mathrm{X} \leq \\
8,0\end{array}$ & Baik \\
\hline $\begin{array}{l}\text { Kepraktisan } \\
\text { penggunaan }\end{array}$ & 23.55 & $\mathrm{X}>20,0$ & Sangat baik \\
\hline
\end{tabular}

Berdasarkan hasil penilaian ahli dan tanggapan guru terhadap 3 aspek yang dinilai, aspek keterbacaan dalam kategori sangat baik, aspek grafik dalam kategori baik dan aspek kepratisan penggunaan dalam ketegori sangat baik. Sehingga dapat disimpulkan bahwa buku petunjuk praktikum yang telah dikembangkan telah layak untuk digunakan.

\section{KESIMPULAN DAN SARAN}

Hasil penelitian ini menunjukkan bahwa praktikum penentuan formalin menggunakan ekstrak ruellla ribosa, hibiscus rosa-sinensis $L$ dan impatiens balsamina $L$ ungu, sedangkan unutk uji borak secara kualitatif dapat dilakukan dengan menggunakan indicator alami bunga Ruellia Simplex, Curcuma Longa, Plumeria Rubra,dan Portulaca Grandiflora. Berdasarkan penilaian ahli dan guru menunjukkan bahwa petunjuk praktikum yang telah dikembangkan layak untuk digunakan.

Penelitian selanjutnya dapat dilakukan dengan menggunakan indicator alami yang lainnya untuk menguji formalin dan boraks. Perlu dilakukan penelitian lanjutan untuk mengetahui mekanisme reaksi yang terjadi dengan adanya pencampuran indicator dengan bahan uji foramalin dan borak.

\section{E. DAFTAR RUJUKAN}

[1] A. S. Irawan and L. S. Ani, "Prevalence Of Rhodamin B Contents, Formalin, And Boraks On Snack And The Description Of Knowledge Official Traders In Basic School Of Susut District, Bangli District," vol. 5, no. 11, pp. 1-6, 2016.

[2] X. Tang, Y. Bai, A. Duong, M. T. Smith, L. Li, and L. Zhang, "Formaldehyde in China: production, consumption, exposure levels, and health effects," Environ. Int., vol. 35, no. 8, pp. 12101224, 2009.

[3] P. A. Fail, R. E. Chapin, C. J. Price, and J. J. Heindel, "General, reproductive, developmental, and endocrine toxicity of boronated compounds," Reprod. Toxicol., vol. 12, pp. 1-8, 1998.

[4] D. Teshima et al., "Clinical management of boric acid ingestion: pharmacokinetic assessment of efficacy of hemodialysis for treatment of acute boric acid poisoning.," J. Pharmacobiodyn., vol. 15, pp. 287-294, 1992.

[5] EFSA, "Opinion of the Scientific Panel on Dietetic Products , Nutrition and Allergies on a request from the Commission related to the Tolerable Upper Intake Level of Boron ( Sodium Borate and Boric Acid ) ( Request N ${ }^{\circ}$ EFSA-Q-2003-018 )," EFSA J., vol. 80, pp. 1-22, 2004.

Q. Li, M. Oshima, and S. Motomizu, "Flowinjection spectrofluorometric determination of trace amounts of formaldehyde in water after derivatization with acetoacetanilide," Talanta, vol. 72, no. 5, pp. 1675-1680, 2007.

[7] T. Katarzyna Różyło, A. Żabińska, and I. RóżyłoKalinowska, "Use of OPLC for quantitation of $\mathrm{HCHO}$, as the dimedone adduct, in human saliva in different dental pathologies," Jpc-Journal Planar Chromatogr. Tlc, vol. 15, no. 1, pp. 19-22, 2002.

[8] B. A. Tomkins, J. M. McMahon, W. M. Caldwell, and D. L. Wilson, "Liquid chromatographic determination of total formaldehyde in drinking water.," Journal-Association Off. Anal. Chem., vol. 72, no. 5, pp. 835-839, 1989.

[9] V. Cogliano, Y. Grosse, R. Baan, K. Straif, B. Secretan, and F. El Ghissassi, "Advice on formaldehyde and glycol ethers," Lancet Oncol., vol. 5, no. 9, p. 528, 2004.

[10] S. Siti-Mizura, E. S. Tee, and H. E. Ooi, "Determination of boric acid in foods: Comparative study of three methods," J. Sci. Food Agric., vol. 55, no. 2, pp. 261-268, 1991.

[11] L. M. Zeng, H. Y. Wang, and Y. L. Guo, "Fast Quantitative Analysis of Boric Acid by Gas Chromatography-Mass Spectrometry Coupled with a Simple and Selective Derivatization 
Reaction Using Triethanolamine," J. Am. Soc. Mass Spectrom., vol. 21, pp. 482-485, 2010.

[12] A. Hakim, A. Kadarohman, and Y. M. Syah, "Effects of the Natural Product Mini Project Laboratory on the Students Conceptual Understanding.," J. Turkish Sci. Educ., vol. 13, no. 2, pp. 27-36, 2016.

[13] K. M. Davies, "An introduction to plant pigments in biology and commerce," Plant Pigment. their Manip., vol. 14, pp. 1-22, 2009.

[14] K. M. Davies, "Modifying anthocyanin production in flowers," in Anthocyanins, Springer, 2008, pp. 49-80.

[15] R. Freyre, C. Uzdevenes, L. Gu, and K. H. Quesenberry, "Genetics and Anthocyanin Analysis of Flower Color in Mexican Petunia," $J$. Am. Soc. Hortic. Sci., vol. 140, no. 1, pp. 45-49, 2015.

[16] K. Torskangerpoll and Ø. M. Andersen, "Colour stability of anthocyanins in aqueous solutions at various pH values," Food Chem., vol. 89 , no. 3, pp. 427-440, 2005.

[17] D. Burdulis, A. Sarkinas, I. Jasutiene, E. Stackeviciene, L. Nikolajevas, and V. Janulis, "Comparative Study of Anthocyanin Composition, Antimicrobial and Antioxidant Activity in Bilberry (Vaccinium Myrtillus L.) and Blueberry (Vaccinium Corymbosum L.) Fruits," Acta Pol. Pharm., vol. 66, no. 4, pp. 399-408, 2009.

[18] P. H. Março, R. J. Poppi, I. S. Scarminio, and R. Tauler, "Investigation of the $\mathrm{pH}$ effect and UV radiation on kinetic degradation of anthocyanin mixtures extracted from Hibiscus acetosella," Food Chem., vol. 125, no. 3, pp. 1020-1027, 2011.

[19] C. T. Du and F. J. Francis, "Anthocyanins of roselle (Hibiscus sabdariffa, L.)," J. Food Sci., vol. 38, no. 5, pp. 810-812, 1973.

[20] Y. Nakamura, M. Hidaka, H. Masaki, H. Seto, and T. Uozumi, "Major anthocyanin of the flowers of Hibiscus (Hibiscus rosa-sinensis L.)," Agric. Biol. Chem., vol. 54, no. 12, pp. 3345-3346, 1990.

[21] P. S. Vankar and D. Shukla, "Natural dyeing with anthocyanins from Hibiscus rosa sinensis flowers," J. Appl. Polym. Sci., vol. 122, no. 5, pp. 3361-3368, 2011.

[22] S. Clevenger, "The flavonols of Impatiens balsamina L," Arch. Biochem. Biophys., vol. 76, no. 1, pp. 131-138, 1958.

[23] J. Lee, R. W. Durst, and R. E. Wrolstad, "Determination of total monomeric anthocyanin pigment content of fruit juices, beverages, natural colorants, and wines by the $\mathrm{pH}$ differential method: Collaborative study," J. AOAC Int., vol. 88, no. 5, pp. 1269-1278, 2005.

[24] O. M. Andersen and K. R. Markham, Flavonoids: chemistry, biochemistry and applications. CRC press, 2005.

[25] A. Gantait, T. Barman, and P. K. Mukherjee, "Validated method for estimation of curcumin in turmeric powder," Indian J. Tradit. Knowl., vol. 10, no. 2, pp. 247-250, 2011.

[26] W. Yj et al., "Stability of curcumin in buffer solutions and characterization of its degradation products . PubMed Commons," J. Pharm. Biomed. Anal., vol. 15, no. 12, pp. 1867-1876, 1997.
[27] R. Byamukama, J. Namukobe, M. Jordheim, Ø. M. Andersen, and B. T. Kiremire, "Scientia Horticulturae Anthocyanins from ornamental flowers of red frangipani, Plumeria rubra," Sci. Hortic. (Amsterdam)., vol. 129, pp. 840-843, 2011.

[28] D. Strack, T. Vogt, and W. Schliemann, "Recent advances in betalain research," Phytochemistry, vol. 62, no. 3, pp. 247-269, 2003.

[29] R. R. Leathers, C. Davin, and J. P. Zrÿd, "Betalain producing cell cultures ofBeta vulgaris L. var. bikores monogerm (red beet),"Vitr., vol. 28, no. 2, pp. 39-45, 1992.

[30] G. Trejo-Tapia et al., "Influence of medium constituents on growth and betalain production in cell suspension cultures of Beta vulgaris," AsiaPacific J. Mol. Biol. Biotechnol., vol. 7, no. 2, pp. 167-172, 1999.

[31] T. Akita, Y. Hina, and T. Nishi, "Production of betacyanins by a cell suspension culture of table beet (Beta vulgaris L.).," Biosci. Biotechnol. Biochem., vol. 64, no. 9, pp. 1807-1812, 2000. 